\title{
Choice of Decorative Paints: Recommendation of Interior Designer and Dealers, an Opinion Survey of Berger Paints Limited, Kolkata
}

\author{
Soumik Gangopadhyay ${ }^{1}$, Pradip Bandyopadhay², Pujashree Sinha ${ }^{2}$ \\ ${ }^{1}$ International Institute of Management Sciences, NH-6, Bombay Road, Palara, Uluberia, \\ P.O. - Mahishrekha, Howrah - 700126, W.B, India. \\ ${ }^{2}$ Berger Paints Limited, 129, Park Street, Kolkata - 700017, India. \\ *E-mail address: soumik74@gmail.com
}

\begin{abstract}
Present study is an opinion survey of the Dealers of Berger Paints Pvt. Ltd., India and Interior designer of Kolkata, India that reveals the factors affecting the choice of paints of the said respondents of Kolkata. The objective of the study was to understand the factors affecting the recommendation of domestic paints with respect to the dealer and interior designer of BERGER Paints Ltd., Kolkata (India). The result denotes some important auxiliary and ancillary factors having an impact on the choice process of the respondents.
\end{abstract}

Keywords: Interior designer; Dealer; Decorative Paints; Brand feature; Psychological factor; Value addition; Berger paints

\section{INTRODUCTION}

Indian Paint industry has a total market size is US\$1400million. The organized sector of the industry is $55 \%$, whereas, the $45 \%$ unorganized sector has about 2500 brands.

According to Indian Paint Association and AC Nielsen, the expected market is 49545 INR crs. by 2016-17 with a prediction of absolute dominance of decorative paint over the industrial market. Estimated market of 2011-12 was 26040 INR cr. (per capita consumption was $2.7 \mathrm{~kg}$.) in which $71 \%$ contributed by the decorative paints contributed by premium range (High \& acrylic emulsions), Medium range (Enamel paints), distemper range (low end paints). Decorative paints are used by Indian consumers for their domestic decorations and incorporate a complex post purchase assessment often performed by them. Purchase of decorative paints happen during house construction, in festive season or pre marriage ceremony. In metro cities like Kolkata, dealers and interior designers often influence the purchase of decorative paint in the choice process of brand/product. 
Table 1. Market share of Indian Paint companies.

\begin{tabular}{|c|c|}
\hline Paint Company Name & Market Share (\%) \\
\hline Asian Paints & 37 \\
\hline Goodlass Nerolac & 15.9 \\
\hline Berger Paint & 13.8 \\
\hline ICI & 11 \\
\hline Jenson \& Nicholson & 5.7 \\
\hline Shalimar & 4 \\
\hline Others & 12.6 \\
\hline Total & $\mathbf{1 0 0}$ \\
\hline
\end{tabular}

Source: www.indiainfoline.com

Berger Paints India Limited (BPIL) is one of India's foremost paint companies, currently ranked as third largest on the basis of consolidated sales turnover in Indian paint industry. Established in 17th December, 1923, the company then known as Hadfiled's (India) Limited; was a small paint company based in Kolkata having its only manufacturing facility at Howrah, West Bengal to produce ready mixed stiff paints, varnishes and distempers. Post independence, towards the end of 1947, British Paints (Holdings) Limited, U.K acquired Hadfield's (India) Limited and thus British Paints (India) Limited was incorporated. From a production capacity of 150 tonnes and sales turnover of around Rs.25 lakh in 1947, the company has come a long way to become a part of the worldwide Berger group in 1983 and thereby acquiring its present name Berger Paints India Limited.

Its present status wherein the majority stake is with Delhi based Dhingra brothers and business revenue more than Rs 2400cr. Today Berger Paints India Limited, having solely used and developed the name and trademark BERGER and all its variants in India, is a household name in paint.

With head office in Kolkata, the company manufactures and markets a range of decorative \& industrial paint products under various product brands and has it operations spread throughout the length \& breath of the country; with seven manufacturing facilities in India and more than 85 depots, several regional $\&$ area offices, besides four facilities overseas. It has a workforce of over 2500 employees and a countrywide distribution network of 15000 plus dealers.

Berger Paints has clearly demonstrated its commitment to Indian consumers for over 88 years, by offering its varied range of high performing quality products backed by highest level of customer service. While the company's decorative and Industrial paints continue to gain an increasing market share, Berger as an organization has managed to achieve sustainable competitive advantage through innovations in all spear of business, desire to excel and by creating a winning culture \& abiding faith in its values \& philosophy among all its stakeholders. 


\section{SURVEY OF LITERATURE}

Marketing scholars and practitioners equally emphasize on the issue of customer satisfaction for generating loyalty among customers, which helps in maintaining existing cash flows and guarantee stable future (Teas, 1994; Zeithaml et al., 1996). Nevertheless, the contradiction in defining customer satisfaction generates further conflicts in defining how to measure it. While the manufacturing sector is concerned with the repurchase, most of the services depend on the continuity and thus focus shifts on customer retention (Anderson et al., 1994). Customer satisfaction constitutes a mental stage in consumer mind where expectation regarding a service or product performance is fulfilled (Goode \& Moutinho, 1996; Oliver, 1989). A review of literature reveled that at least two different conceptualizing of customer satisfaction construct exist.

Transaction specific conceptualize customer satisfaction as one time post purchase evaluation (Oliver, 1977). On the other hand, cumulative satisfaction refers to overall evaluation after usage for a period of time (Anderson et al., 1994; Fornell, 1992; Fornell et al., 1996). It costs more to gain a new customer than to retain an existing one (Woodruff, 1997). Moreover, customer switches brands due to pricing, inconvenience, core service failure, service encounter failure, response to service failure, competition, ethical problems, and involuntary switching (Keaveney, 1995). Hence, brand name (Aaker, 1996), price (Cadogan \& Foster, 2000), promotion (Cherniawski \& Maloney, 1999), and quality stimulates brand loyalty.

However, fundamental basis of consumer's values of a brand is a unique combination of perceived quality and perceived price (Mowen and Minor, 2006) that influence prepurchase behavior of a customer (Wall et al. 1991). Dowling and Staelin (1994) revealed that evaluations, choice and behavious are the fundamental theme of customer's perception regarding risk which is defined in the form of uncertainty and consequences. Higher the level of uncertainty is, more the risk is perceived and creates greater negative consequences (Oglethorpe \& Monroe, 1994).

However, consumer's values of a brand on the basis of an unique combination of perceived quality and perceived price (Mowen and Minor, 2006). Customers even purchase brand by country habit and the coutry-of-origin has a strong impact on their purchase (Hahn et al. 2006; Pappu 2007; Lee \& Ganesh 1999; Knight et al. 2007). Rahman et al. 2013 has critically analysed and concluded that customers of developing country having strong ethnocentric tendency may not necessarily perceive domestic product as higher quality compared to the imported one may be on moral ground.

Lower income groups of Indian consumers are becoming the target of the corporate managers as they purport significantly greater materialistic value than the higher income group in the post globalization era (Gupta N., 2011). Different researchers defined and redefined different buying situations depending on the problem faced, information influenced to the buyer and consideration of new alternatives by the decision maker of a buying process (Sudar et al. 2012).

Marketers must understand the factors that provoke a feeling of risk in consumers \& provide information \& support to reduce perceived risk. Risks experienced by the customer collects information from personal source, market controlled sources, public sources, personal experiences. 


\section{OBJECTIVES OF THE STUDY}

The objective of the study is to meet academic obligation and to explore the factors effecting recommendation of paints of the dealer and interior designer to help the practicing managers of Berger Paints Ltd., Kolkata to design their paints more acceptable in the market.

a. To know the factors effecting the choice of paints of the dealer and interior designer.

b. To reveal the preference of deciding the recommendation of paints of the said respondents.

c. To identify, study and analyze the factors of designing of paints from the marketing perspective.

\section{METHODOLOGY OF THE STUDY}

The study is based on a field survey done on 50 Interior designer of Kolkata (India) and 50 official dealers of Berger Paints Ltd. using questionnaire technique. They are being selected as sample of the study. Secondary data of the study is sourced from different articles, company websites, articles of reputed journals. The data so collected has been analysed with the help of software named STATA. Motivation of recommendation of purchase can depend on many factors. Hence it is a challenge of the marketing manager to extract correct factors that functions as the antecedents of recommendation of paints of the designer and or dealer.

Therefore, in this case Principle Component Analysis (factor analysis) has been used to derive the main factors from the twelve different variables considered.

\section{DATA ANALYSIS AND INTERPRETATION}

The variables that are considered as affecting opinion of choice of paints to recommend are 12 variables affecting post purchase behavior of the interior designer and dealers to recommend are texture of colour, variety of colour, durability of paint, image of brand, company services, quality of the product, availability of the product, cost of application of the paint, peer pressure, promotional offers, bad smell of paint brands. PCA analysis has generated three factors with Eigen value more than 1. The Factor analysis (Principle Component Analysis) done in this case emanated three factors by analyzing are as follows,

Factor 1 - Variety of colour, Durability of paint, Quality of paint

Factor 2 - Bad image

Factor 3 - Promotional offer

The results of the PCA are summarized in the following tables below:

Table 2. Eigenvalue of the components.

\begin{tabular}{|c|c|c|c|c|}
\hline Component & Eigenvalue & Difference & Proportion & Cumulative \\
\hline Comp 1 & 3.42694 & 1.99527 & 0.3115 & 0.3115 \\
\hline Comp 2 & 1.43167 & 0.136725 & 0.1302 & 0.4417 \\
\hline Comp 3 & 1.29494 & 0.296779 & 0.1177 & 0.5594 \\
\hline Comp 4 & 0.998164 & 0.129287 & 0.0907 & 0.6502 \\
\hline
\end{tabular}




\begin{tabular}{|c|c|c|c|c|}
\hline Comp 5 & 0.868877 & 0.0876358 & 0.079 & 0.7291 \\
\hline Comp 6 & 0.781241 & 0.0871093 & 0.071 & 0.8002 \\
\hline Comp 7 & 0.694132 & 0.0681394 & 0.0631 & 0.8633 \\
\hline Comp 8 & 0.625993 & 0.171082 & 0.0569 & 0.9202 \\
\hline Comp 9 & 0.45491 & 0.133842 & 0.0414 & 0.9615 \\
\hline Comp 10 & 0.321068 & 0.321068 & 0.0292 & 0.9907 \\
\hline Comp 11 & 0.102064 & 0.0093 & 1 & \\
\hline
\end{tabular}

Source: Primary data analysis

Table 3. Principal Component Analysis (PCA).

\begin{tabular}{|c|c|c|c|c|c|c|c|}
\hline Variables & Comp 1 & Comp 2 & Comp 3 & Comp 4 & Comp 5 & Comp 6 & Comp 7 \\
\hline Texture & 0.1828 & -0.506 & 0.0902 & -0.0176 & 0.5568 & 0.0022 & 0.3891 \\
\hline Variety of Colour & 0.4703 & -0.1738 & 0.067 & -0.0679 & -0.2729 & 0.0828 & -0.1217 \\
\hline Durability & 0.4612 & -0.1536 & -0.0085 & 0.0005 & -0.2514 & 0.1897 & -0.0574 \\
\hline Brand image & 0.0408 & 0.4043 & 0.4703 & 0.2778 & 0.3656 & 0.3086 & -0.4518 \\
\hline Company Services & 0.3409 & 0.2262 & 0.1137 & -0.1524 & 0.444 & -0.0792 & 0.1158 \\
\hline Quality of the product & 0.4433 & 0.1784 & -0.0913 & -0.0595 & 0.1676 & -0.0172 & 0.153 \\
\hline Availability & 0.2306 & -0.3404 & 0.3561 & 0.4247 & -0.2494 & 0.1287 & -0.078 \\
\hline Cost of Application & 0.2968 & 0.3023 & -0.2966 & -0.4225 & -0.1123 & 0.226 & -0.1255 \\
\hline Peer's Recommendation & 0.0647 & 0.2739 & -0.4523 & 0.6421 & -0.0111 & 0.3163 & 0.406 \\
\hline Offer (Deal) & -0.1841 & 0.1592 & 0.4776 & -0.3091 & -0.2345 & 0.4862 & 0.5655 \\
\hline Bad smell & 0.1972 & 0.3688 & 0.3123 & 0.1566 & -0.252 & -0.6718 & 0.2881 \\
\hline
\end{tabular}

Source: Primary data analysis

\section{CONCLUSION}

However, it can conclude that, paint companies including Berger Paint must design their product by concentrating on the features of the paints. So, interior designer and dealer recommend the domestic paints on the basis of brand features (variety, durability, quality). Psychological image or promotional offers given to them takes a anciliary factor to them affecting their choice process.

Marketing department must consider the brand features not the value added service as a factor of designing the marketing strategy of Berger paint products. Further, advertising of 
paint brands can be designed giving emphasis on its physical features. Interior designer and dealers are to be incorporated in marketing policy decision of promoting Berger paint brands.

\section{References}

[1] Aaker A. David, California Management Review 38(3) (1996) 101-120.

[2] Anderson E. W., Fornell C., Lehmann D. R., Journal of Marketing 58 (1994) 53-66

[3] Cadogan J. W., Foster B. D., Marketing Intelligence and Planning 18(4) (2000) 185-199.

[4] Cherniawski R. D., Maloncy M. W., Creating brand loyalty: the management of power positioning and really great advertising, New York: AMACOM, American Management Association, 1999.

[5] Dowling G., Staelin R., Journal of Consumer Research 21(1) (1994) 19-34

[6] Goode M., Moutinho L., Journal of professional service marketing 13(2) (1996) 93-112.

[7] Gupta Nitin., Asia Pacific Journal of Marketing and Logistics 23(3) (2011) 251-269.

[8] Hahn S., Choin M., Eckhardt G., Made in Asia - an exploration of country of origin effects within the region, Paper presented at the Asia Pacific Conference, 2006.

[9] Fornell C., Journal of Marketing 55 (1992) 1-21.

[10] Fornell C., Johnson M. D., Anderson E. W., Cha J., Bryant B. E., Journal of Marketing 60 (1996) 7-18.

[11] Keaveney M. Susan, Journal of Marketing 59(2) (1995) 71-82.

[12] Knight J. G., Holdsworth, D. K., Mather, D. W., Journal of International Business Studies 38(2007) 107-125.

[13] Lee D., Ganesh G., Journal of International Marketing Review 16(1) (1999) 18-41.

[14] Mowen J., Minor M., Consumer behavior, a framework. Englewood Cliffs, NJ: Prentice-Hall, 2006, pp. 27-65.

[15] Oglethorpe J. E., Monroe K. B., Journal of consumer affairs 28(2) (1994) 326-347.

[16] Oliver R. L., Journal of Applied Psychology 62 (1977) 246-250.

[17] Oliver, R. L., Journal of consumer satisfaction, Dissatisfaction and complaining behaviour 2(1989) 1-16.

[18] Papadopoulos N., Heslop N., Journal of Brand Management 9(4-5) (2002) 294-314.

[19] Pappu R., Quester P. G., Cooksey R. W., Journal of International Business Studies 38(2007) 726-745.

[20] Rahman Sabbir Muhammad, Hussain Bashir, Hussain Mehedi, Khan Highe Abdul., International Centre for Business Research 2(1) (2013)136-141.

[21] Sudar S. C., A, Reddy R.V., International Journal of Research Excellence in Management 1(1) (2012) 1-5.

[22] Teas R. K., Journal of Marketing 58 (1994) 132-139. 
[23] Wall M., Liefeld J., Heslop L. A., Journal of the Academy of Marketing Science 19(2) (1991) 105-13.

[24] Woodruff Robert B., Journal of the Academy of Marketing Science 25(2) (1997) 139-153.

[25] Zeithaml V. A., Berry L. L., Parasuraman A., Journal of Marketing 60 (1996) $31-46$

[25] http://www.bergerpaintsindialimited.com (Accessed on 24.09.12)

[26] http://www.indiainfoline.com/Markets/News/Indian-Paint-Market-expected-to-reach49545-INR-Crs-by-2016-2017-IPA-Study/5589228799 (Accessed on 23.03.13) 